This is the peer reviewed version of the following article:

Oubelkacem, A., Scardigno, A. and Choukrallah, R. (2020), Treated Wastewater Reuse on Citrus in Morocco: Assessing the Economic Feasibility of Irrigation and Nutrient Management Strategies. Integr Environ Assess Manag. doi:10.1002/ieam.4314

which has been published in final form at https://doi.org/10.1002/ieam.4314.

This article may be used for non-commercial purposes in accordance with Wiley Terms and Conditions for Use of Self-Archived Versions 


\title{
Treated Wastewater Reuse on Citrus in Morocco: Assessing the Economic Feasibility of Irrigation and Nutrient Management Strategies
}

\author{
Abdellah Oubelkacem, $\dagger$ Alessandra Scardigno, ${ }^{*}+$ and Redouane Choukrallah $\neq$ \\ $\digamma$ CIHEAM-Mediterranean Agronomic Institute of Bari, Bari, Italy \\ Department of Horticulture, Hassan II Institute of Agronomy and Veterinary Medicine, Rabat, Morocco
}

\begin{abstract}
Reuse of treated wastewater (TWW) for irrigation can be an effective strategy in Mediterranean countries to overcome the pressure on freshwater resources if its economic viability is demonstrated. In this work, the assessment of the economic feasibility of irrigation and nutrient management with TWW reuse was carried out in the citrus sector in the Souss Massa region of Morocco. Considering the effects of TWW reuse on yields, water, and fertilizer requirements, a mathematical nonlinear optimization model was used to identify the optimal allocation of land and nonuniform quality irrigation water and to assess the impacts on the economic performance of the citrus sector. Different water price and irrigation technology scenarios have been simulated. Overall results indicated that the reuse of TWW-with a current price higher than the conventional resource-must be subsidized to be proposed as a convenient alternative for irrigation. A reduction in the TWW price from its current level $\left(0.23 \mathrm{Euro} / \mathrm{m}^{3}\right)$ to a level equal to that of fresh water $\left(0.15 \mathrm{Euro} / \mathrm{m}^{3}\right)$ would encourage farmers to use TWW on $59 \%$ of the total cultivated area, leading to a $350 \mathrm{~mm}$ reduction in quantity of used fresh water per hectare.
\end{abstract}

Keywords: Treated wastewater reuse Citrus Economic feasibility Optimization model Mediterranean region

\section{INTRODUCTION}

Morocco, being a Mediterranean country, is suffering from a severe water shortage. Water resources are limited due to the semiarid to arid climate in the major part of the country. Annual irregularity, interannual variability, and heterogeneity of spatial distribution of precipitations mainly influence the hydrological status of Morocco. With a population of 35.9 million persons (HCP 2020) water availability per capita is less than $1000 \mathrm{~m}^{3}$, placing Morocco at the water poverty threshold. This situation requires solutions and alternatives to ensure water security, and the reuse of treated wastewater is indeed a promising option to reduce the pressure on the water resources (MED-EUWI 2007; Hanjra et al. 2012). Treated wastewater is a source of water that is always available (Aziz and Farissi 2014), and it can balance the natural cycle of water and conserve resources by reducing the discharge of harmful emissions in the

* Address correspondence to scardigno@iamb.it environment (Bouchet 2008) and the pressure of fresh water sources (Winpenny et al. 2013). By reducing irrigation costs and the cost of extracting groundwater resources, the reuse of treated wastewater offers poor farmers more opportunities for investing in crop diversification and moving toward a large agriculture benefit (Molinos-Senante et al. 2011; El-Zanfaly 2015), thereby ensuring food security (FAO 2005; Corcoran 2010; Jaramillo and Restrepo 2017; UNWWAP 2017). Nutrients present in wastewater allow savings of fertilization costs (Corcoran 2010; Winpenny et al. 2013) and ensure a favorable nutrient cycle that avoids the indirect return of micro and macro elements to the water bodies. Finally, treated wastewater can also have a positive effect on crop yield (Toze 2006; Bixio et al. 2008). On the other hand, the use of treated wastewater for irrigation can cause potential risks to human health (Gerba and Rose 2003) related to the accumulation of emerging contaminants (ECs) and to the environment, especially on the soil. Soil physiochemical parameters, structure, magnitude, and activity of microbial biomass have been shown to be affected by irrigation with treated wastewater 
(Becerra-Castro et al. 2015) that cause alterations in soil fertility and productivity.

Having tripled in the last 3 decades, the yearly volume of discharged raw wastewater in Morocco is currently about 900 million $\mathrm{m}^{3}$ (MI 2019). Around $60 \%$ of this water is discharged to the sea, and the remaining quantity is divided between the draining-off of surface waters and reuse processes (Choukr-Allah 2012). Despite the interest shown by the public department of agriculture for the reuse of this resource (MI 2019), only about 80 million $\mathrm{m}^{3}$ of treated wastewater is used in agriculture, including: artificial recharge of the aquifer in the region of Gharb (Northwest), forest trees irrigation in (Kenitra), irrigation of pastures and grazing grounds, golf courses, and landscape irrigation (Benzine 2012; Choukr-Allah 2013; El Oualja 2013; Aziz and Farissi 2014).

The use of treated wastewater for citrus irrigation is not a new practice in Mediterranean countries (Pereira et al. 2011) and in Morocco (Omran et al. 1988; Zekri and Dinar 2003). The success of treated wastewater reuse for citrus irrigation is largely attributed to well-drained soils (Pereira et al. 2011), appropriate treatment technologies, and adequate irrigation management strategies. The separation between fruits and irrigation water reduces the chances for pathological contamination; nevertheless, given the sensitivity of citrus to salinity and to $B$, water quality characteristics of the treated wastewater can injure trees, impact fruit production, and affect fruit quality if present at high concentrations (Grattan et al. 2015). On the other hand, treated wastewater irrigation positively affects citrus nutrition by increasing the amount of $\mathrm{P}, \mathrm{Ca}$, and $\mathrm{K}$.

Citrus production represents a very prominent sector in the national agricultural context: with a current area of 125000 ha and an average production of around 2 million tons/y the citrus production sector contributes substantially to the improvement of farmers' incomes, and this sector numbers about 13000 and significantly affects employment through the creation of nearly 25 million working days per year. Annual production almost doubled from 2002 to 2017 to reach 2.36 million tons (MAPMDERF 2017), and, with an export which fluctuates around 500000 tons/y, citrus represents one of the main sources of foreign currency in Morocco. The citrus industry has differentiated its offers with a diversified and specific varietal profile to meet the specific requirements of the international citrus market (MAPMDERF 2017).

Quality standards required in the markets, as well as a lack of knowledge about treated wastewater effects on yield, fertilization, and economic feasibility limit the current use of treated wastewater for citrus irrigation in Morocco. Together with irrigation methods, appropriate irrigation scheduling that takes into account the quality of the treated wastewater used are also crucial issues (Choukr-Allah 1993). Therefore, a comprehensive analysis of crop response, irrigation practices, and economic evaluations of potential benefits is needed when using treated wastewater to irrigate citrus fruits. Bioeconomic models can help capture the complexity of interactions between water management systems and the economy and find a suitable combination of resources and their allocations while maximizing multiple-objective functions (Amir and Fisher 1999; Valunjkar 2007). In the agricultural sector, specific attention is given to minimizing yield losses with maximum total net income, minimizing salt concentration in the water system and irrigated land, and minimizing the total operational cost of the system (Atilhan et al. 2012; Ghassemi and Danesh 2013; Molinos-Senante et al. 2015; Graveline 2016; Abdulbaki et al. 2017; Reca et al. 2018). At the basin scale, bioeconomic models have been used to analyze alternative policy scenarios for water allocation and use by making physical and economic dimensions of water distribution clear to policymakers (George et al. 2011; Esteve et al. 2015) in order to assess the potential effects of climate change on irrigated agriculture and options of adaptation, as well as to identify the optimal allocation of nonuniform quality irrigation water (Reca et al. 2018).

In the context outlined above, the use of an optimization model, which simulates alternative scenarios that introduce the availability of treated wastewater for irrigation, will allow for the achievement of the following objectives: 1) identify the optimal allocation of land and water irrigation of nonuniform quality between crops; and 2) assess the economic performance of farmers and, ultimately, the economic feasibility of reusing the treated wastewater.

By promoting recycling and the safe reuse of treated wastewater to irrigate, the present study intends to contribute to SDG targets 6.3, "By 2030, improve water quality by reducing pollution, eliminating dumping, and minimizing release of hazardous chemicals and materials, halving the proportion of untreated wastewater and substantially increasing recycling and safe reuse globally," and 6.4, "By 2030, substantially increase water-use efficiency across all sectors and ensure sustainable withdrawals and supply of freshwater to address water scarcity and substantially reduce the number of people suffering from water scarcity," and to their economic components in particular.

\section{MATERIAL AND METHODS}

\section{The optimization model}

A nonlinear stochastic, single-year comparative static mathematical programming model, written by GAMS, General Algebraic Modelling System language (Rosenthal 2011), was used to select the optimal allocation of land and nonuniform quality irrigation among different activitiesdefined as a combination of crop varieties and water quality-that maximizes a given objective. The optimization takes into consideration various parameters (both agronomic and economic), such as different quality of irrigation water, crop irrigation and fertilizing requirements, irrigation techniques, water and land availability, crop cultivation cost, crop yield, crop price and crop price variation, water and fertilizers costs, and farmers' risk aversion (Figure 1). 


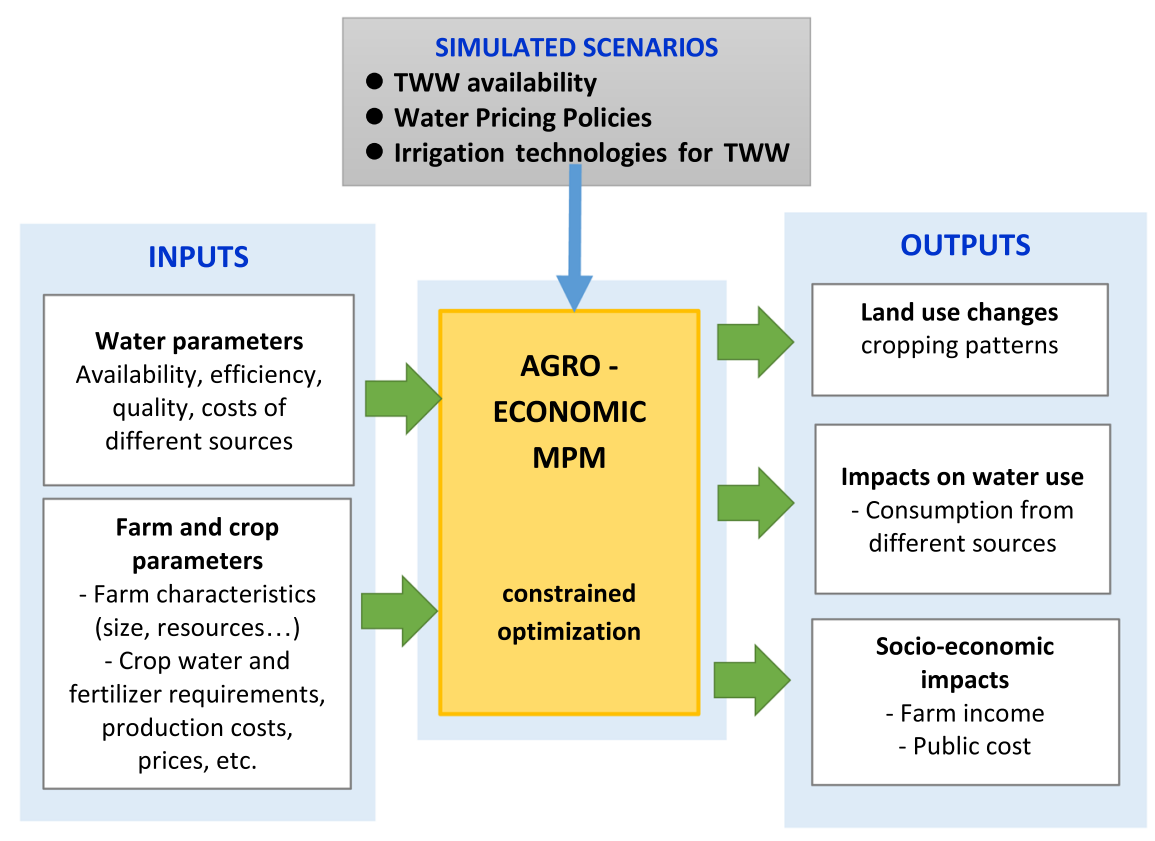

Figure 1. Flowchart of the adopted model.

The adopted model follows a primal-based approach, where technology is explicitly represented through the use of engineering production coefficients-that is, needed quantities of inputs such as water, fertilizers, labor, etc. to produce one unit of a given product-generated from agronomic theory and biophysical models. These engineering coefficients constitute the essential linkage between the biophysical and economic models, allow for switching between production processes defined in a transparent way (Flichmann et al. 2011) and "provide the possibility of a complicated but easy to handle description of production possibility set" (Boussard 2011). Assuming the farmer to be a rational agent, the model's main objective is to reproduce the observed production situation and the observed behavior (Janssen and Van Ittersum 2007). Once the model is calibrated by changing the parameters (i.e., prices, subsidies), it can be used for making predictions. It is a comparative static model which optimizes an objective function for a single period (i.e., 1 y) over which decisions are taken. This implies that it does not explicitly take temporal dynamics into account.

\section{Objective function}

The model's objective is to maximize the farmers' annual expected utility defined, following the mean-standard deviation approach with a constant absolute risk aversion (CARA) specification (Markowitz 1952; Pratt 1976), as the expected income minus its standard deviation due to risk aversion toward income variation that can be generated by many factors, primarily market crop price and crop yield variation. The CARA approach is widely employed in agricultural models because, by implying a utility function almost quadratically in the parameters, it simplifies the resolution of the optimization programming problems (Arribas et al. 2020).

According to the adopted approach, the objective function is formulated as follows

$$
\operatorname{Max} U=Z-\phi * \sigma,
$$

where $U$ is utility function; $Z$ is the expected income (Euro); $\phi$ is the risk aversion coefficient; and $\sigma$ is the standard deviation of the expected income.

The risk aversion coefficient $(\phi)$ is a parameter that measures the degree of willingness and the ability of farmers to take risk. Assuming a normal distribution of the random values of $Z$, the coefficient ranges between 0 and 1.96: when it equals 0 , the farmer is risk neutral and when it equals 1.96, the farmer is almost totally risk averse since 1.96 is the approximate value of the 97.5 percentile point of the standard normal distribution, that is to say that $95 \%$ of the area under a normal curve lies within roughly 1.96 standards of deviation of the mean. It follows that when the parameter $\phi$ is equal to 0 , the maximized value, $U$, is equal to the expected, $Z$, but more uncertain; when the parameter assumes positive values, the maximized value is less than the expected income but with a greater probability of occurrence.

The expected income $(Z)$ is defined by the following Equation:

$$
Z=\left(\sum_{c, q}{G M A R G_{c, q}} * X_{c, q}-\text { WATused }_{q} * \text { pricewat }_{c, q}\right),
$$

where the index $c$ represents the set of citrus varieties subject to the model simulation (Clementine, Maroc late, 
Nadorcott, Navel, and Nour); the $q$ index indicates the water quality (fresh or treated wastewater); GMARG is the Gross margin (Euro per hectare); $X$ is the activity level (ha); WATused $q$ is the amount of water used per source $\left(\mathrm{m}^{3}\right)$; and Pricewat is the Price of water $\left(E u r o / \mathrm{m}^{3}\right)$.

Similarly to $Z$, a number of random incomes $Z_{k}$ is calculated using the same equation for the expected income calculation. The difference is that the average prices are replaced by 100 random prices defined over different states of nature $\left(K_{p}\right)$. The random element (price) is a vector of independent numbers randomly generated and normally distributed, which means they are calculated using a normal distribution function based on the average and standard deviation of the price:

$$
\sigma=\sqrt{\sum_{k p} \frac{\left(Z K_{p}-Z\right)}{100}},
$$

The gross margin is mathematically expressed as

$$
\begin{aligned}
\operatorname{GMARG}_{c, q}= & \left(\left(Y_{c, q}\right) *\left(\operatorname{Pr}_{c}-\operatorname{Pr}_{c} * \varepsilon * \text { diff }_{c}\right)\right)-v c_{c} \\
& - \text { tech_cost }_{c, q}-\sum_{f} \text { fertreq }_{f, c, q} * \text { fertpr }_{f}
\end{aligned}
$$

where $\operatorname{Pr}$ is the crop price (Euro/t); $Y$ is the crop's yield (t/ha); $\varepsilon$ is the coefficient of price elasticity to supply that measures the reaction of supply (crop activity level) to a unitary change of price of products (\%); diff is the coefficient of area variation; $v c$ is the total variable costs (Euro); $f$ is the index for fertilizers; fertreq is fertilizers' requirement $(\mathrm{kg} / \mathrm{ha})$ given by the sum of amounts of fertilizers per hectare for each crop; Fertpr is the price of fertilizers (Euro/kg); and tech_cost is the irrigation equipment cost (Euro/ha).

The coefficient of area variation (diff) is a factor introduced to account for the differences between the cropping pattern suggested and the cropping pattern already existing in the study area. It was introduced for the purpose of calibration and is mathematically expressed as follows

$$
\operatorname{diff}_{c}=\frac{\sum_{q,} X_{c, q} * Y_{c, q}-\sum_{q} \text { IniArea }_{c} * Y_{c, q}}{\sum_{q} \ln \text { Inirea }_{c} * Y_{c, q}},
$$

where IniArea is the initial area for each crop (ha).

Water and fertilizers used are computed through the following additional equations

$$
\begin{gathered}
\text { WATused }_{q}=\sum_{c, m}\left(\frac{N I R_{c, m}}{\text { htech }}\right) \cdot X_{c, q} \\
\text { FERTused }_{f, q}=\sum_{c, i} \text { fertreq }_{f, c, q} * X_{c, q}
\end{gathered}
$$

where $m$ is the month index; NIR is net irrigation requirements $\left(\mathrm{m}^{3} / \mathrm{ha}\right)$; Htech is the technical efficiency of irrigation system; and Fertreq is the amount of fertilizer for each varieties ( $\mathrm{kg} / \mathrm{ha})$.

\section{Model constraints}

The optimization model works under different constraints that are related to land, water, and fertilizer availability. The land constraint implies that the land allocation for crops should not exceed total land availability for each month Mathematically, this constraint is expressed as follows

$$
\text { fland }_{m}=\sum_{c, q} X_{c, q} * L_{-} \text {use }_{c, m} \leq \text { fland, }
$$

where fland is the farm agricultural land availability (ha) and L_use is the land use per crop and per month.

As for water, the constraint implies that for each water resource, the sum of water requirements for all crops should be less or equal to the water availability for each month. Mathematically, the constraint is expressed as follows

$$
\sum_{c} \text { WATused }_{q, c, m} \leq \text { watsup }_{q, m} * \text { fland },
$$

where WATused is the amount of water used for water resource, crop and month $\left(\mathrm{m}^{3} / \mathrm{ha}\right)$ and watsup is the total water supply $\left(\mathrm{m}^{3} / \mathrm{ha}\right)$.

\section{Calibration of the model and sensitivity analysis}

In order to develop a model to help in the decisionmaking process, so as to make it usable for policy analysis, its simulation capacity has to be tested and model calibration is needed. The calibration consists of feeding the model with input data of the actual situation and comparing one or more simulated outputs with the observed one. Measures of goodness of fit can be used to check how closely the model calibrates the empirical levels of cropped areas, production, prices, and levels of input use. In our case, cropping pattern-the combination of citrus variety and irrigation water resource-which is the main decision variable and is easily observable in the field, has been used to compare the actual and the simulated scenarios. The underlying assumption of this choice is that the current cropping pattern is likely to be the optimal one for a given farming system and the current conditions in terms of water availability, irrigation technologies, and water policies. Both the risk aversion coefficient $(\varnothing)$ and the coefficient of price elasticity $(\varepsilon)$ could be used to calibrate the model. Their values have been changed inside specific ranges according to input data based on previous work (Gil and Ben Kaabia 2004), until the attainment of an optimal situation where the percent absolute deviation (PAD) between the observed and predicted cropping pattern is the lowest one (Janssen et al. 2010). As a result of the calibration process, the model has been calibrated by using the risk aversion coefficient $(\varnothing)=0$ and the elasticity coefficient of the price $\varepsilon=0.96$; the PAD obtained is less the $4 \%$. The identified optimal solution is considered to be the "baseline scenario."

Finally, a sensitivity analysis was conducted to ascertain the response of the simulation model's results to changes in its input parameters and to determine "the contributions of individual uncertain analysis inputs to uncertainty in the 
Table 1. Main input data for the selected varieties

\begin{tabular}{|c|c|c|c|c|c|c|c|}
\hline Variety & $\begin{array}{l}\text { Area } \\
\text { (ha) }\end{array}$ & $\begin{array}{l}\text { Yields } \\
\text { (ton/ha) }\end{array}$ & $\begin{array}{l}\text { Price } \\
\text { (Euro/t) }\end{array}$ & $\begin{array}{l}\text { Net Irr } \\
\text { Req. (mm) }\end{array}$ & $\begin{array}{l}\text { Variable costs } \\
\text { (Euro/ha) }\end{array}$ & $\begin{array}{c}\text { Ammonium } \\
\text { nitrate }(\mathrm{kg} / \mathrm{ha})\end{array}$ & $\begin{array}{l}\text { Mono ammonium } \\
\text { phosphate }(\mathrm{kg} / \mathrm{ha})\end{array}$ \\
\hline Clementine & 12527 & 30 & 700 & 562 & 4.800 & 570 & 68 \\
\hline Navel & 4.750 & 40 & 950 & 629 & 5.000 & 603 & 77 \\
\hline Maroc Late & 8.981 & 45 & 890 & 699 & 5.000 & 612 & 78 \\
\hline Nour & 4.840 & 40 & 760 & 534 & 4.900 & 571 & 65 \\
\hline Nadorcott & 1.194 & 65 & 1.100 & 976 & 4.740 & 558 & 73 \\
\hline
\end{tabular}

analysis results" (Helton et al. 2006). The most uncertain inputs are usually considered: in this work, the crops' fertilizer requirement variation (reduction) of the use treated wastewater and of the farmer's income. The initial value of the simulated quantity of fertilizer required, given in Table 1, was changed to a plus or minus of $30 \%$ and the model was run for scenarios 2,3 , and 4 .

\section{Case study area}

The Souss Massa region is located in the center of Morocco (Figure 2) with a total area of $12000 \mathrm{~km}^{2}$ distributed between the plain of Souss $\left(4150 \mathrm{~km}^{2}\right)$, the plain of Massa $\left(1600 \mathrm{~km}^{2}\right)$, and mountainous areas of the High and Anti-Atlas $\left(6250 \mathrm{~km}^{2}\right)$. The agricultural area is $228500 \mathrm{ha}$ and 143640 ha are actually irrigated. The Souss Massa is one of the first agricultural regions in the country (Choukr-Allah et al. 2007) and contributes almost $60 \%$ of the national citrus fruits and $85 \%$ of vegetables exports. The region has a semiarid to subdesert climate: the annual average temperature is $19^{\circ} \mathrm{C}$, the average maxima is $27^{\circ} \mathrm{C}$ and the minima is $11^{\circ} \mathrm{C}$, with a generally high sunshine rate. Surface water supplies of the region are characterized by irregularity as well long and severe droughts, with the average rainfall not exceeding $200 \mathrm{~mm} / \mathrm{y}$ in the plains and $600 \mathrm{~mm} / \mathrm{y}$ in the mountain summits (Hermas 2017). Renewable potential

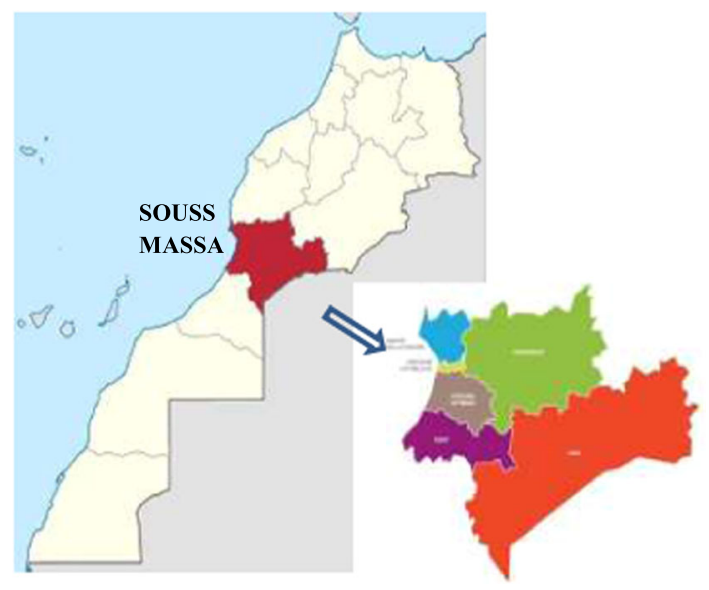

Figure 2. Souss Massa region. in groundwater is about 425 million $\mathrm{m}^{3} / \mathrm{y}$ on average. The current balance of the Souss aquifer is a deficit of 271 million $\mathrm{m}^{3} / \mathrm{y}$ with significant drawdowns of the water table mainly due to the extension of irrigated areas and to an increasing demand on potable water (MEMEED 2015; $A B H S M$ 2019). In the area of action of the hydraulic basin agency (ABHSM) of the Souss Massa, agricultural water demand was estimated at 1268 million $\mathrm{m}^{3} / \mathrm{y}$ in 2019, including 582 million $\mathrm{m}^{3} / \mathrm{y}$ of groundwater (AFD 2012); $40 \%$ of the agricultural water demand in the region is assigned for citrus production.

Citrus production occupies an area of 40343 ha, which represents one-third of the total citrus area in Morocco; $30 \%$ of farms in the region have areas larger than 5 hectares and represent $99 \%$ of the total area (Abaouz 2013). The choice of the variety is based on its productivity, response to stress, resistance to certain diseases, and the market demand: the main varieties are Clementine (31\%), Maroc late (22\%), Navel (12\%), and Nour (12\%) (Kjidaa 2017). The citrus production in the Souss-Massa region during the last years has been subjected to variation-from 400000 ton in 2012/2013 to 800000 ton in 2016/2017-due to several factors, such as severe climatic events and market fluctuations.

Farmers are grouped in cooperatives that offer services related to technical consultancy, assistance for irrigation, fertilization and phytosanitary treatments, as well as produce commercialization to the international market. Due to increasing stress on local aquifers, farmers also rely on surface water for part of their irrigation needs. The volumetric tariff does not vary according to the volume of water consumed, and there is no fixed tariff applied to each unit of cultivated land. Each farm is equipped with an on-farm-storage reservoir that insures an autonomy of at least 2 weeks of irrigation needs. All farms are equipped with drip irrigation systems that have a high efficiency level and allow the ferti-irrigation practices adoption.

\section{Input data}

The input data for the optimization model were collected through the consultation of an official statistical database (MAPMDERF 2017), direct communication with farmers, and the consulting of public authorities in charge of agriculture management during fieldwork carried out for 2 months (April and May 2018). 
All collected data are referred to as the campaign 2016/ 2017. Yields refer to the full irrigation for the normal irrigation (100\% ETc) and the prices are those registered in the international market. The efficiency for drip irrigation systems is set to $95 \%$. Water price is equal to $0.15 \mathrm{Euro} / \mathrm{m}^{3}$ for fresh water and 0.23 Euro $/ \mathrm{m}^{3}$ for treated wastewater given the cost of treatment technologies. Yields, net irrigation requirements, and fertilizers' requirements pertaining both to fresh and treated wastewater were taken from previous work (Oubelkacem 2018) carried out in the same area where the safe irrigation management (SIM) model (Dragonetti et al. 2020) was applied to assess the effects of different quality waters on crop yield and the water balance and establish a correct irrigation and nutrient management strategy.

Wastewater, treated to a tertiary level using ultra violet rays, has the following characteristics: $\mathrm{pH} \mathrm{7.08;} \mathrm{EC}$ at $25^{\circ} \mathrm{C}$ 4.24 (dS/m); $\mathrm{Cl}$ (mg/L) 777.84; $\mathrm{HCO}_{3}-(\mathrm{mg} / \mathrm{L})$ 493.76; $\mathrm{NO}_{3}-$ (mg/L) 230.86; P (mg/L) 5.65; Ca (mg/L) 449.11; $\mathrm{Na}$ (mg/L) 104.30; $\mathrm{Mg}$ (mg/L) 56.63; and K (mg/L) 34.30 .

Costs represented in the equations of gross margins were calculated according to the data provided by local farmers during the data collection campaign. The cost for fertilizers is excluded from the total variable costs and considered as a separate element. Nitrogen is supplied to the plant in the form of $\mathrm{NH}_{4} \mathrm{NO}_{3}$, which contains 33\% of $\mathrm{N}$. Phosphorus is supplied in the form of mono ammonium phosphate (MAP), containing $62 \%$ of $\mathrm{P}_{2} \mathrm{O}_{5}$. The 2 fertilizers are sold in the market for the prices of 0.32 Euro $/ \mathrm{kg}$ and 0.89 Euro $/ \mathrm{kg}$, respectively.

\section{Simulation scenarios}

Beyond the baseline, 3 scenarios have been considered and described in terms of: cropping pattern, different water quality use, fertililzer use, farm income, and public subsidies. They are:

1) Baseline (calibration) scenario: corresponding to the actual situation where an amount of $8000 \mathrm{~m}^{3} / \mathrm{y} / \mathrm{ha}$ of fresh water is available with a price equal to $0.15 \mathrm{Euro} / \mathrm{m}^{3}$ and an efficiency of the drip irrigation system equal to $95 \%$.

Treated wastewater is not available to farmers. It represents the reference for the comparison and analysis of the simulation scenarios.

2) Water availability scenario: Treated wastewater is added as an irrigation water source. According to the results obtained in previous research (Oubelkacem 2018), reduced fertilizer requirements, $-80 \%$ and $-30 \%$ for $\mathrm{NH}_{4} \mathrm{NO}_{3}$ and MAP, respectively, have been considered when treated wastewater is used to irrigate. Both fresh water and treated wastewater, with their current prices, are considered (where the price of treated wastewater, $0.23 \mathrm{Euro} / \mathrm{m}^{3}$, is higher than that of fresh water, $0.15 \mathrm{Euro} / \mathrm{m}^{3}$ ). The efficiency of the drip irrigation system is equal to 0.85 for treated wastewater and 0.95 for fresh water. The efficiency is considered lower in the case of treated wastewater since the low quality affects the functioning of the system via clogging and salt accumulation in the pipes (Bounoua et al. 2016).

3) Policy scenarios: The policy scenario accounts for the high and nonsubsidized price of treated wastewater compared to fresh water. A water pricing policy is simulated and 2 cases were studied, the first sets equal prices for both fresh and treated wastewater $\left(0.15\right.$ Euro $\left./ \mathrm{m}^{3}\right)$, while the second sets the price of treated wastewater $\left(0.09 \mathrm{Euro} / \mathrm{m}^{3}\right)$ as lower than fresh water $\left(0.15\right.$ Euro $\left./ \mathrm{m}^{3}\right)$. The policy scenario implicates the adoption of subsidies to assist and encourage farmers to use treated wastewater as an irrigation water source.

4) Technology scenario: A new technology, micro sprinklers, adapted to the irrigation with treated wastewater, was proposed with an annual cost estimated between 350 and 400 Euro/ha. The effect of the new technology appears in the efficiency of the irrigation system, as this technique is well adapted for irrigation with low quality waters. An application efficiency of 0.95, an additional cost of treated wastewater technology of 350 Euro/ha, and an availability of fresh water and TWW at their current prices are simulated together with the introduction of a possible subsidy for the installation of new technologies.

\section{RESULTS AND DISCUSSIONS}

The baseline (calibration) scenario

Simulation in the baseline scenario shows a similar cropping pattern to the actual situation to a level of $96.16 \%$ so that the model was considered to be well calibrated. The chosen citrus varieties are distributed as follows: Clementine makes up $39 \%$ of the total area, Navel is $15 \%$, Maroc late occupies $28 \%$, Nour is planted on $15 \%$, and Nadorcott is planted on $4 \%$ of the total land.

The total and average water quantities used in the baseline scenario are equal to $218449511 \mathrm{~m}^{3}$ and $6764 \mathrm{~m}^{3} / \mathrm{ha}$, respectively, while the amounts of fertilizing elements used per unit of area are presented in Table 2.

For the baseline scenario, the total cost of water and the average cost per unit of area amount to 32767427 Euro and 1014 Euro/ha, respectively. Considering all costs and benefits, the total farmers' income is calculated. The average income per unit of area is obtained by dividing the total

Table 2. Quantities of fertilizing elements used in the baseline scenario

Ammonium nitrate $(\mathrm{kg})$

18930949

Ammonium nitrate $(\mathrm{kg} / \mathrm{ha})$

586.2

Mono ammonium phosphate $(\mathrm{kg})$

2319828

Mono ammonium phosphate $(\mathrm{kg} / \mathrm{ha})$ 
income by the cultivated land. The baseline scenario's total income is equal to 274000360 Euro, which is equivalent to 8485 Euro/ha.

\section{Water availability scenario (SO1)}

The results of this scenario have shown that TWW, while available, are not used, and reuse does not appear in the optimal solution as an irrigation water source. The cultivated land is totally irrigated with fresh water and, consequently, the amount of water used, the total and average water costs, the total and average fertilizer amounts, and the farmers' incomes remain the same compared to the baseline scenario.

\section{Policy scenarios (S02 and S03)}

Given the nonappearance of the TWW as a source for irrigation in the availability scenario, 2 policy scenarios are simulated: scenario $\mathrm{SO} 2$ where the price of TWW is set equal to fresh water; scenario $\mathrm{SO3}$ where the price for TWW is lower than fresh water.

\section{Scenario S02: equal prices}

Land allocation according to water sources has changed since $59 \%$ of the total area switched to treated wastewater (Figure 3).

Given the lower efficiency level that the system reaches when TWW are used, in order to satisfy the net irrigation requirements of each variety, the average amount of TWW used is higher than the average amount of fresh water. For this reason, the varieties that switched to TWWClementine, Nour, and a part of Navel-are those with the lowest annual water requirements, and the changeover to TWW, considering the greater requirements of gross irrigation, can be offset by savings in fertilizers. As land allocation according to the water source has changed, the annual amount of water used for each source will also change, as shown in Table 3.

The total and average water costs for scenario S02 are equal to 34806153 Euro and 1078 Euros/ha, respectively. By comparing the average amount of fertilizer used for crops irrigated with fresh water with the average amount used for crops irrigated with TWW, results show that TWW

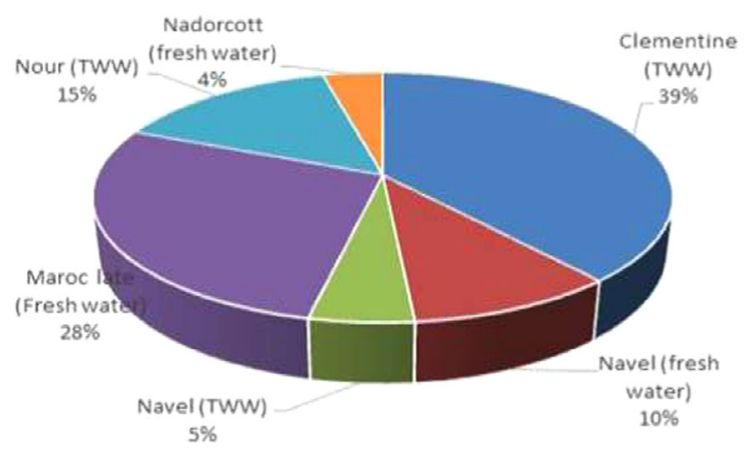

Figure 3. Land allocation according to water source for the scenario S02.
Table 3. Amount of water used per source for the S02 scenario

Fresh water $\left(\mathrm{m}^{3}\right)$

102873019

Fresh water $\left(\mathrm{m}^{3} / \mathrm{ha}\right)$

7.746

TWW $\left(\mathrm{m}^{3}\right)$

129168000

$\operatorname{TWW}\left(\mathrm{m}^{3} / \mathrm{ha}\right)$

6.794

allows for the saving of important amounts of fertilizers (81\% of $\mathrm{NH}_{4} \mathrm{NO}_{3}$ and $38 \%$ of MAP). The combined effects of an increase in the cost of water and a reduced cost for fertilizers translates into a higher total income and average income per hectare that equal to 2750903030 Euro and $8518 \mathrm{Euro} / \mathrm{ha}$, respectively.

\section{Scenario S03: Lower price for TWW}

Land allocation according to the 2 water sources remains the same as in scenario S02, with the same varieties switching to TWW. Similarly, as land allocation remains the same, the total quantities of water used for each water source also remain identical, as do the quantities of fertilizing elements used.

The difference between scenarios $\mathrm{S02}$ and $\mathrm{S03}$ resides in the total and average cost of water for the farmers that, in scenario S03, are equal to 27056073 Euro and 838 Euro/ha, respectively.

Consequently, as the cost of water changes, the farmer's incomes will change to reach the value of 282840383 Euro and 8759 Euro/ha for annual total income and average farmer's income, respectively.

\section{Technology scenario (SO4)}

In this scenario, the new micro sprinkler technology developed in the framework of the MADFORWATER project has been introduced into the model. This technology is assumed to retrieve the loss of application efficiency, due to its compatibility with low-quality water sources. Therefore, the application efficiency of the irrigation system is increased to $95 \%$, coupled with an additional annual cost for the implementation of this technology (350 Euro/ha).

Results show that TWW does not appear to be an adequate source for irrigation in this scenario. The total land irrigated with freshwater is identical to the baseline scenario. Similarly, the total and average amounts of water used, and the fertilizer amounts, are the same as in the baseline scenario. The annual average cost of water as well as the farmer's income also remain the same compared to the baseline scenario.

Results demonstrate that the farmers' decision about the use of TWW only changes in scenarios $\mathrm{S02}$ and S03, where the price of TWW is subject to a certain level of subsidies. Compared with the baseline scenario, $59 \%$ of the total land switches to TWW as a source for irrigation. On the the other hand, in scenarios S01 and S04, the total land is irrigated with fresh water. We can also deduce that the switch from 


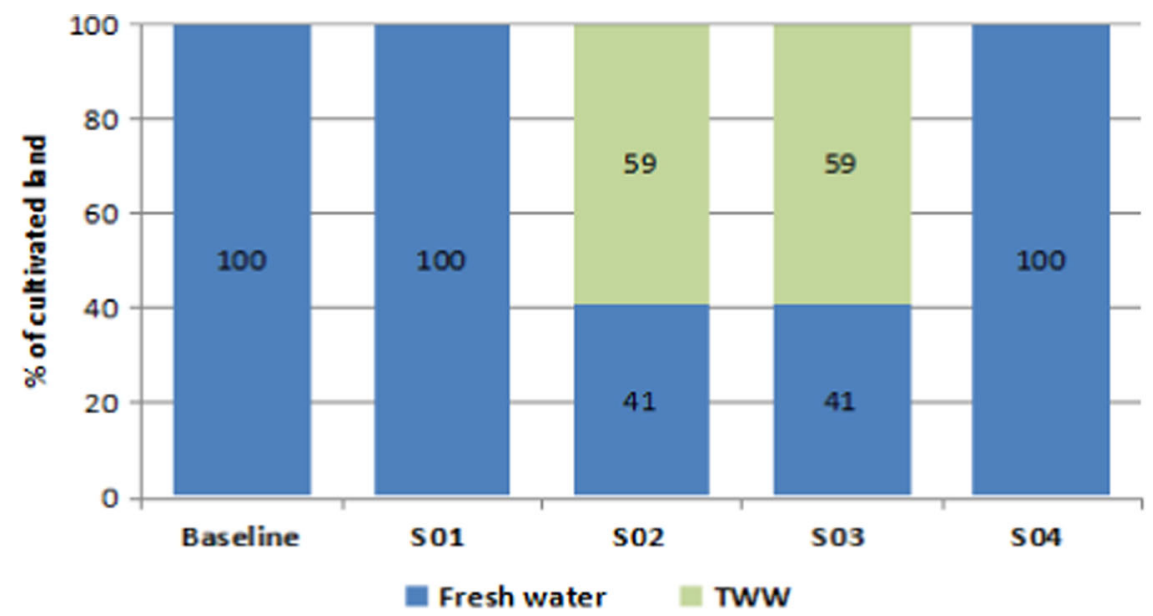

Figure 4. Land allocation (in \%) according to water source.

fresh water to TWW happens for varieties with the least annual water requirements, which is due to the difference between fresh water and TWW in terms of application efficiency. Therefore, the least water demanding crops will be less affected by this loss.

As shown in Figure 4, the substitution of fresh water with TWW allows for the conservation of an average amount of $358 \mathrm{~mm}$ of fresh water per hectare. This important amount could have a great socio-economic value, since it could be used for other crucial activities, such as drinking water.

The reduced amounts of fertilizing elements required for irrigation with treated wastewater (Figure 5) result in lower production costs for the farmer, thereby confirming impressive results for cereals, forage, and vegetables already documented in the literature (Hamdy and Choukr-Allah 2003). In scenarios S02 and S03 (Figure 5), where TWW is used for irrigation, the total amounts of fertilizers saved compared to the baseline scenario are equal to $81 \%$ for Nfertilizer and $38 \%$ for $P$ which means economic savings for the farmer and a contribution to environmental welfare.

The average annual water costs for scenarios S01 and S04 are identical to the baseline scenario, since the total land is irrigated with fresh water, while in scenario S02, where the prices of fresh water and TWW are equal $\left(0.15 \mathrm{Euro} / \mathrm{m}^{3}\right)$, the average annual water cost is higher than in the baseline scenario since, on the $59 \%$ of the land switched to TWW, the lower application efficiency leads to the need for larger water amounts to meet the net irrigation requirements for the plants. On the other hand, in scenario S03, where the price of TWW $\left(0.09 \mathrm{Euro} / \mathrm{m}^{3}\right)$ is lower than fresh water, the annual water cost has decreased when compared to the baseline scenario, considering that the land allocation is the same as in scenario S02. This indicates that subsidies on water costs are needed to cover the difference in water

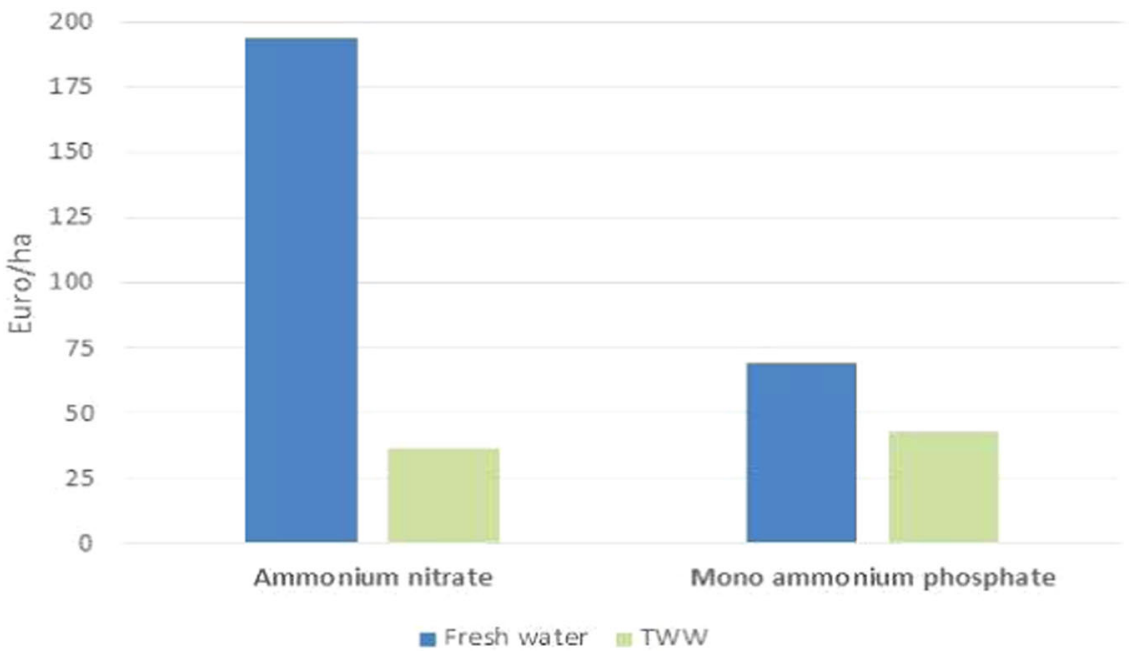

Figure 5. Fertilizers costs and savings for TWW use. 

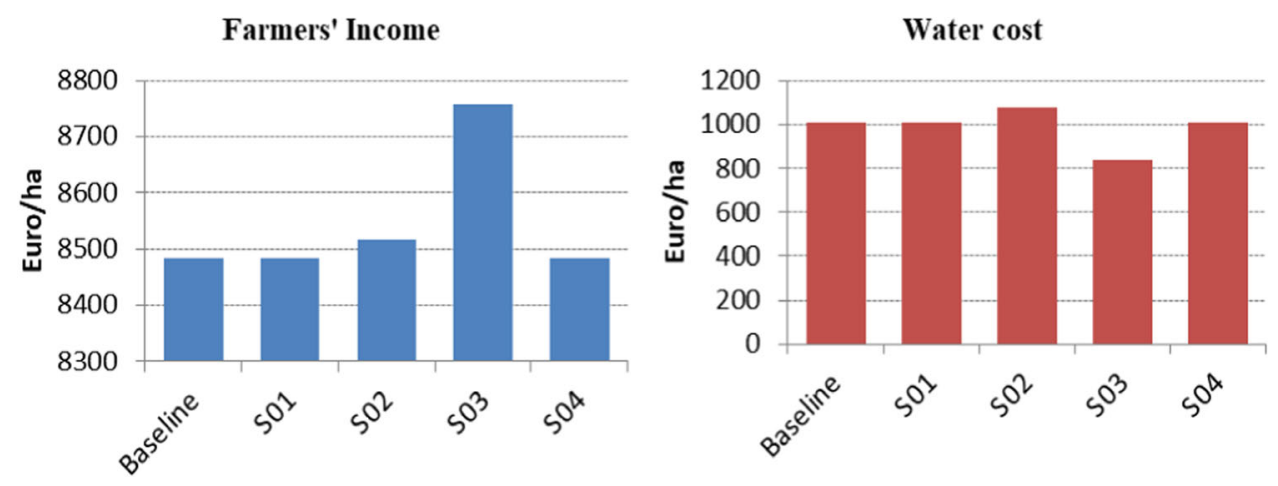

Figure 6. (A) water cost and (B) farmers' income for the different scenarios.

consumption due to the loss of application efficiency (Figure 6).

In scenarios $\mathrm{SO} 2$ and $\mathrm{S03}$, the average annual income increases respectively by $0.38 \%$ and $3.22 \%$, with respect to the baseline scenario, due to the combined effects of saving on the cost of fertilizers and subsidies.

The subsidies per hectare of land irrigated with TWW, equal to 544 and 952 Euro respectively in scenarios S02 and S03, decrease to 320 and 561 Euro if calculated on the total cultivated area, thereby ammounting to much lower levels than the increase induced in the income of farmers. Subsidizing the price of TWW could be justified from a social point of view only if the value of the saved freshwater is equal to the difference between the amount of subsidies and the increment in the farmer's income. Different simulations have been carried out while gradually decreasing the cost of TWW from its actual level $\left(0.23 \mathrm{Euro} / \mathrm{m}^{3}\right)$ to a level equal with fresh water $\left(0.15 \mathrm{Euro} / \mathrm{m}^{3}\right)$, but the switch to TWW only occurs at the level of cost equality.

In the case of scenario S04, the micro sprinkler technology adapted to low-quality waters was introduced and simulations were carried out assuming that additional costs for the implementation of this technology are subsidized, keeping the cost of TWW at its actual level. As shown in the results of scenario S04, TWW is not suggested as an optimal solution for irrigation, even when the technology cost is subsidized, since the gain in efficiency allowed by the technology does not help to account for difference in water cost.

The results of the sensitivity analysis given in Table 4 show that, in any simulated scenario, the change in fertilizer requirements is not sufficient to change the farmer's decision on the use of treated wastewater. On the other hand, as expected, the farmer's income is sensitive, albeit slightly, and it is positively correlated to the need for fertilizers. The analysis of the sensitivity results demonstrates the robustness of the results obtained by the model.

\section{CONCLUSIONS}

The present research, integrating biophysical input in an economic model, allowed for the investigation of some of the key issues related to the reuse of treated wastewater in the citrus sector of the Souss Massa region in Morocco. The methodological approach of combining agronomic data in the economic model made it possible to manage and optimize irrigation water use, considering climatic, socio-economic, and environmental constraints.

Table 4. Sensitivity analysis results

$\Delta$ Fertilizer requirement

$-30 \%$

Input data
Farmer's Income (Euro/ha)

Land irrigated with freshwater (ha)

Land irrigated with TWW (ha)

Farmer's income (Euro/ha)

Land irrigated with freshwater (ha)

$30 \%$
Land irrigated with TWW (ha)

Farmer's income (Euro/ha)
8546

13280

19012 
The integrated model allows for the replication of the farmers' behavior and determines the optimal allocation of different quality waters under different constraints and in different pricing, technology, and policy scenarios. The results obtained show that the private advantage of saving fertilizer costs could be significant, but, with the current price level for the 2 water sources $\left(0.15 \mathrm{Euro} / \mathrm{m}^{3}\right.$ and 0.23 Euro $/ \mathrm{m}^{3}$ for fresh and TWW respectively), this positive effect is insufficient to make the reuse an option, thereby confirming the low demand for treated wastewater reported in the literature (Jeuland 2015).

The economics of reuse will not be favorable as long as water prices remain so far below the cost or scarcity value of water so long as, like in our case study, users do not suffer acute shortage and have a choice between conventional and TWW water.

The increase in TWW supply must be associated with a good water resource design policy that fills the widespread lack of effective price signals (El Yacoubi and Belghiti 2002) and restructures the reuse funding. In fact, with subsidies equal to 0.08 Euro $/ \mathrm{m}^{3}$ for the TWW used by farmers, $59 \%$ of the cultivated land is irrigated with TWW and $3580 \mathrm{~m}^{3} /$ ha of fresh water are saved. Even the continuous decreases in the treatment cost of treated wastewater (Frascari et al. 2018) could contribute to its reuse only if transferred in price signal. In addition, the evaluation of saved fresh water could help to raise public awareness of the effectiveness of and opportunities for reuse, emphasizing the "social benefit" generated by this reuse.

Combining the obtained results, it can be concluded that the TWW reuse promotion and enhancement is required to overcome the lack of adequate information about benefits (Massoud et al. 2019), incomplete economic analysis of TWW reuse options, misalignment between water prices and water scarcity, and lack of economic incentives for reuse (Frascari et al. 2018).

For future research, it could be interesting to consider that the conditions and assumptions on the basis of which these results have been obtained could change. An increasing water scarcity for the agricultural sector could eliminate the choice between the sources that is still available in the Moroccan irrigation sector, and a total or partial substitution of fresh water with different sources of nonuniform quality irrigation water (Reca et al. 2018) could have a significant impact on the desirability of treated wastewater (Reznik et al. 2019). Dynamic optimization methods could be the most appropriate for tackling this issue.

Acknowledgment-This research was undertaken in the context of the MADFORWATER project funded from the EU Horizon 2020 research and innovation program under grant agreement No. 688320 (MADFORWATER project; www. madforwater.eu).

Disclaimer-The authors declare no conflicts of interest.

Data Availability Statement-Data and associated metadata and calculation tools are available upon request by contacting the corresponding author Scardigno Alessandra (scardigno@iamb.it).

\section{ORCID}

Alessandra Scardigno http://orcid.org/0000-0001-9196-1090

\section{REFERENCES}

Abaouz N. 2013. Etude technico-économique de la production d'un verge de clémentinier dans la région du Souss [Masters thesis]. Agadir (MA): Institut Agrnomique et Vétérinaire Hassan 2 (IAV), Complexe Horticole d'Agadir.

Abdulbaki D, Al-Hindi M, Yassine A, Abou Najm M. 2017. An optimization model for the allocation of water resources. J Clean Prod 164:994-1006.

[ABHSM] Agence du Bassin Hydraulique de Souss-Massa. 2019. Etude de révision du plan directeur d'aménagement intégré des ressources en eau (PDAIRE) des bassins du Souss Massa: Présentation au Ministère-DRPE, 5 May 2019. [accessed 2020 Apr 5]. http://abhsm.ma/index. php/partenariat2/evenements

AFD. 2012. Gestion de la demande en eau dans les pays méditerranéens. Gestion de la demande en eau: Etude du cas du Maroc. Agence française de développement. [accessed 2018 Mar 24]. http://cmimarseille.org/sites/ default/files/newsite/AFD/presentations/AFD_Synthese_VFran.pdf

Amir I, Fisher FM. 1999. Analyzing agricultural demand for water with an optimizing model. Agric Syst 61(1):45-56. https://doi.org/10.1016/S0308$521 \times(99) 00031-1$

Arribas I, Louhichi K, Perni A, Vila JE, Gómez y Paloma S. 2020. Modelling agricultural risk in a large scale positive mathematical programming model. Int J Comput Econ Econom 10(1):2-32.

Atilhan S, Mahfouz AB, Batchelor B, Linke P, Abdel-Wahab A, Nápoles-Rivera F, Jiménez-Gutiérrez A, El-Halwagi MM. 2012. A systems-integration approach to the optimization of macroscopic water desalination and distribution networks: A general framework applied to Qatar's water resources. Clean Technol Environ Policy 14(2):161-171. https://doi.org/10. 1007/s10098-011-0387-8

Aziz F, Farissi M. 2014. Reuse of treated wastewater in agriculture: Solving water deficit problems in arid areas (review). Ann West Univ Timişoara Biol XVII(2):95-110.

Becerra-Castro C, Lopes AR, Vaz-Moreira I, Silva EF, Manaia CM, Nunes OC. 2015. Wastewater reuse in irrigation: A microbiological perspective on implications in soil fertility and human and environmental health. Environ Int 75(Suppl C):117-135. https://doi.org/10.1016/j.envint.2014.11.001

Benzine L. 2012. Réutilisation des eaux usées épurées dans le bassin de Souss Massa. Journée de sensibilisation sur Les Potentialités et Perspectives de la Réutilisation des Eaux Usées Dans la Région du Sous Massa. Agadir (MA).

Bixio D, Thoeye C, Wintgens T, Ravazzini A, Miska V, Muston M, Chikurel H, Aharoni A, Joksimovic D, Melin T. 2008. Water reclamation and reuse: Implementation and management issues. Desalination $218(1-3)$ 13-23.

Bouchet C. 2008. Recyclage et réutilisation des eaux usées: Ou en sommesnous? Eau, I'INDUSTRIE, les Nuis 308:33-42.

Bounoua S, Tomas S, Labille J, Molle B, Granier J, Haldenwang P, Izzati NS. 2016. Understanding physical clogging in drip irrigation: In situ, in lab and numerical approaches. Irrig Sci 34:327-342.

Boussard JM. 2011. Bio physical models as detailed engineering production functions. In: Flichman G, editor. Bio-economic models applied to agricultural systems. Dordrecht (NL): Springer Netherlands. p 15-28.

Choukr-Allah R. 1993. Municipal wastewater reclamation and reuse: Moroccan experiences. In: Hamdy A, editor. Advanced short course on sewage: Treatment-practices-management for agriculture use in the Mediterranean countries. Valenzano (IT): CIHEAM Bari. p 603-609.

Choukr-Allah R. 2012. Perspectives of wastewater reuse in the Mediterranean region. In: Choukr-Allah $\mathrm{R}$, Ragab $\mathrm{R}$, Rodriguez-Clemente $\mathrm{R}$, editors. Integrated water resources management in the Mediterranean region: Dialogue towards new strategy. Dordrecht (NL): Springer Netherlands. p 125-137.

Choukr-Allah R. 2013. Interventions to increased efficiency and effectiveness of treated wastewater reuse in agriculture in the Mediterranean Region. In: Proceedings of the International Conference on Sustainable Water Use for Securing Food Production in the Mediterranean Region under 
Changing Climate; 2013 Mar 10-15. Agadir (MA): IAV Hassan II; University of Copenhagen.

Choukr-Allah R, Bellouch H, Baroud A. 2007. Gestion intégrée des ressources en eau dans les bassins du Souss Massa. In: Bogliotti C, Karaa K, Karam F, Lamaddalena $\mathrm{N}$, editors. Harmonization and integration of water saving options. Convention and promotion of water saving policies and guidelines: Bari: CIHEAM/EU DG Research. Options Méditerranéennes: Série B. Etudes et Recherches. Malta (MT): CIHEAM/EU DG Research. 67-69.

Corcoran E. 2010. Sick water? The central role of wastewater management in sustainable development: A rapid response assessment: UNEP/Earthprint. [accessed 2018 May 16]. http://hdl.handle.net/20.500.11822/9156

Dragonetti G, Khadra R, Daccache A, Oubelkacem A, Choukrallah R, Lamaddalena N. 2020. Development and application of a predictive model for treated wastewater irrigation management in a semiarid area. Integr Environ Assess Manag. https://doi.org/10.1002/ieam.4307

El Oualja H. 2013. Étude de trois projets de réutilisation des eaux usées épurées (REUE) en valorisation industrielle, en sylviculture et en recharge de nappe. AC, Rabat—4 février 2013. [accessed 2018 Jun 2]. https:// agire-maroc.org/4-5-fevrier-2013-atelier-dechanges-sur-lelaboration-dunprogramme-national-dassainissement-et-de-reutilisation-en-milieu-rural/

El Yacoubi Z, Belghiti M. 2002. Valuation of irrigation water-The case of Morocco. In: Baroudy E, Lahlou AA, Bayoumi A, editors. Water demand management forum on water valuation, Beirut, Lebanon. Beirut (LB): IWA Publishing

El-Zanfaly HT. 2015. Wastewater reuse in agriculture: A way to develop the economies of arid regions of the developing countries. J Environ Prot Sustain Dev 1(3):144-158.

Esteve P, Varela-Ortega C, Blanco-Gutiérrez I, Downing TE. 2015. A hydroeconomic model for the assessment of climate change impacts and adaptation in irrigated agriculture. Ecol Econom 120:49-58. https://doi. org/10.1016/j.ecolecon.2015.09.017

FAO. 2005. L'irrigation en Afrique en chiffres. FAO Rapports sur l'eau. Rome (IT). [accessed 2018 May 6]. http://www.fao.org/3/a-a0232f.pdf

Flichmann G, Louhichi K, Boisson JM. 2011. Modeling the relationship between agriculture and the environment using bio-economic models: Some conceptual issues. In: Flichman G, editor. Bio-economic models applied to agricultural systems. Dordrecht (NL): Springer Netherlands. p 3-14.

Frascari D, Zanaroli G, Motaleb MA, Annen G, Belguith K, Borin S, ChoukrAllah R, Gibert C, Jaouani A, Kalogerakis N et al. 2018. Integrated technological and management solutions for wastewater treatment and efficient agricultural reuse in Egypt, Morocco, and Tunisia. Integr Environ Assess Manag 14(4):447-462. https://doi.org/10.1002/ieam.4045

George B, Malano H, Davidson B, Hellegers P, Bharati L, Massuel S. 2011. An integrated hydro-economic modelling framework to evaluate water allocation strategies I: Model development. Agric Water Manag 98(5): 733-746. https://doi.org/10.1016/j.agwat.2010.12.004

Gerba C, Rose J. 2003. International guidelines for water recycling: microbiological considerations. Water Sci Technol: Water Supply 3(4):311-316.

Ghassemi SA, Danesh S. 2013. A hybrid fuzzy multi-criteria decision making approach for desalination process selection. Desalination 313:44-50. https://doi.org/10.1016/j.desal.2012.12.008

Gil JM, Ben Kaabia M. 2004. Deliverable 23: Synthetic report: Import demand analysis for fruits and vegetables in the European Union: An application to the orange market. Market and trade policies for Mediterranean agriculture: The case of fruit/vegetable and olive oil (MEDFROL). [accessed 2018 Jun 5]. https://eumed-agpol.iamm.fr/html/publications/prj_report/ default.html

Grattan SR, Díaz FJ, Pedrero F, Vivaldi GA. 2015. Assessing the suitability of saline wastewaters for irrigation of Citrus spp.: Emphasis on boron and specific-ion interactions. Agric Water Manag 157:48-58.

Graveline N. 2016. Economic calibrated models for water allocation in agricultural production: A review. Environ Model Softw 81:12-25. https://doi. org/10.1016/j.envsoft.2016.03.004

Hamdy A, Choukr-Allah R. 2003. Sustainability and optimisation of treatments and reuse of wastewater in agriculture: case of Morocco. In: Hamdy A, editor. Regional Action Programme (RAP): Water resources management and water saving in irrigated agriculture (WASIA PROJECT): Bari: CIHEAM. Options Méditerranéennes: Série B. Etudes et Recherches.
Malta (MT): CIHEAM/EU DG Research. p 77-87. http://om.ciheam.org/ om/pdf/b44/03001796.pdf

Hanjra MA, Blackwell J, Carr G, Zhang F, Jackson TM. 2012. Wastewater irrigation and environmental health: Implications for water governance and public policy. Int J Hyg Environ Health 215(3):255-269. https://doi. org/10.1016/j.ijheh.2011.10.003

[HCP] Haut-Commissariat au Plan. 2020. Projections de la population totale du Maroc par age simple et sexe 2014-2050. [accessed 2020 Apr 22]. https:// www.hcp.ma/Projections-de-la-population-totale-du-Maroc-par-age-simpleet-sexe-2014-2050_a2209.html

Helton JC, Johnson JD, Sallaberry CJ, Storlie CB. 2006. Survey of samplingbased methods for uncertainty and sensitivity analysis. Reliab Eng Syst Saf 91(10-11):1175-1209.

Hermas H. 2017. Eau: Le Souss-Massa face au défi d'une gestion intégrée et durable. Agence marocaine de presse. In: 13th edition of the World Wide Workshop for Young Environmental Scientists (WWW-YES-2013)-Urban waters: resource or risks?; 2013 Jun 3-7; Arcueil, France. HAL-ENPC.

Janssen S, Louhichi K, Kanellopoulos A, Zander P, Flichman G, Hengsdijk H, Meuter $E$, Andersen E, Belhouchette $H$, Blanco $M$ et al. 2010. A generic bio-economic farm model for environmental and economic assessment of agricultural systems. Environ Manag 46(6):862-877.

Janssen SJC, Ittersum M. 2007. Assessing farm innovations and responses to policies: A review of bio-economic farm models. Agric Syst 94:622-636.

Janssen SJC, Van Ittersum MK. 2007. Assessing farm innovations and responses to policies: A review of bio-economic farm models. Agric Syst 94(3):622-636

Jaramillo MF, Restrepo I. 2017. Wastewater reuse in agriculture: A review about its limitations and benefits. Sustainability 9(10):1734. https://doi. org/10.3390/su9101734

Jeuland M. 2015. Challenges to wastewater reuse in the Middle East and North Africa. Middle East Dev J 7(1):1-25. https://doi.org/10.1080/ 17938120.2015 .1019293

Kjidaa M. 2017. Etude du comportement de certaines variétés du clémentinier vis-à-vis du climat de l'année en cours et l'évaluation de l'impact climatique sur la production agrumicole durant les dernières années dans le Souss. Agadir (MA): Institut Agrnomique et Vétérinaire Hassan 2 (IAV), Complexe Horticole d'Agadir.

MAPMDERF. 2017. L'agriculture Marocaine en chiffres 2016. Maroc: Ministère de l'agriculture, de la pêche maritime, du développement rural et des eaux et forêts. [accessed 2018 Feb 2]. www.agriculture.gov.ma/sites/ default/files/agriculture_en_chiffres_2016_pdf

Markowitz H. 1952. Portfolio selection. J Finance 7(1):77-91. https://doi.org/ 10.1111/j.1540-6261.1952.tb01525.x

Massoud MA, Terkawi M, Nakkash R. 2019. Water reuse as an incentive to promote sustainable agriculture in Lebanon: Stakeholders' perspectives. Integr Environ Assess Manag 15(3):412-421. https://doi.org/10.1002/ ieam. 4131

MED-EUWI M. 2007. Mediterranean wastewater reuse report: Mediterranean wastewater reuse working group (MED WWR WG). [accessed 2019 Jun 6]. https://ec.europa.eu/environment/water/blueprint/pdf/med_final_report. pdf

MEMEED. 2015. Ministère de l'énergie, des Mines, de l'Eau et de l'Environnement. Département de l'eau. [accessed year month day]. http:// www.water.gov.ma/ressources-en-eau/presentation-generale/

MI. 2019. Ministère de l'Intérieur Direction Générale des Collectivités Locales DEA-DRSC, Assainissement liquide au Maroc, Atelier sur la mobilisation des eaux usées traitées et des eaux de drainage pour le développement agricole en Afrique du Nord. [accessed 2020 Apr 8]. www.maroc.ma/fr/ actualites/mme-el-ouafile-plan-integre-dassainissement-liquide-en-mileurural-vise-traiter-43

Molinos-Senante M, Gomez T, Caballero R, Hernandez-Sancho F, SalaGarrido R. 2015. Assessment of wastewater treatment alternatives for small communities: An analytic network process approach. Sci Total Environ 532:676-687. https://doi.org/10.1016/j.scitotenv.2015.06.059

Molinos-Senante M, Hernandez-Sancho F, Sala-Garrido R. 2011. Cost-benefit analysis of water-reuse projects for environmental purposes: a case study for Spanish wastewater treatment plants. J Environ Manag 92(12): 3091-3097. https://doi.org/10.1016/j.jenvman.2011.07.023 
Omran MS, Waly TM, Abd Elnaim EM, El Nashar BMB. 1988. Effect of sewage irrigation on yield, tree components and heavy metals accumulation in navel orange trees. Biol Wastes 23(1):17-24. https://doi.org/10.1016/ 0269-7483(88)90041-9

Oubelkacem A. 2018. Treated wastewater use on citrus in Morocco: Assessing the economic feasibility of irrigation and nutrient management strategies [Masters thesis]. Valenzano (IT): CIHEAM Bari.

Pereira BFF, He ZL, Stoffella PJ, Melfi AJ. 2011. Reclaimed wastewater: Effects on citrus nutrition. Agric Water Manag 98(12):1828-1833. https:// doi.org/10.1016/j.agwat.2011.06.009

Pratt J. 1976. Risk aversion in the small and in the large. Econometrica 32(1/2): 122-136. https://doi.org/10.2307/1912743

Reca J, Trillo C, Sánchez JA, Martínez J, Valera D. 2018. Optimization mode for on-farm irrigation management of Mediterranean greenhouse crops using desalinated and saline water from different sources. Agric Syst 166:173-183. https://doi.org/10.1016/j.agsy.2018.02.004

Reznik A, Dinar A, Hernández-Sancho F. 2019. Treated wastewater reuse: An efficient and sustainable solution for water resource scarcity. Environ Resour Econ 74(4):1647-1685.
Rosenthal RE. 2011. GAMS: A user's guide. Washington (DC): GAMS Development Corporation. [accessed 2020 Jul 8]. https://www.gams.com/ latest/docs/UG_Tutorial.html

Toze S. 2006. Reuse of effluent water-Benefits and risks. Agric Water Manag 80(1):147-159. https://doi.org/10.1016/j.agwat.2005.07.010

[UNWAPP] United Nations World Water Assessment Programme. 2017. The United Nations World Water Development Report 2017: Wastewater, the untapped resource. Paris (FR): UNESCO. [accessed 2019 Jun 12]. http://unesco.org/new/en/natural-sciences/environment/water/wwap/wwdr/ 2017-wastewater-the-untapped-resource

Valunjkar S. 2007. Optimization of water resources for cropping pattern under sustainable conditions through fuzzy logic system. WIT Trans Ecol Environ 102:1-10.

Winpenny J, Heinz I, Koo-Oshima S, Salgot M, Collado J, Hérnandez F, Torricelli R. 2013. Reutilización del agua en agricultura: Beneficios para todos Rome (IT): FAO. [accessed 2018 Sep 12]. http://www.fao.org/3/a-i1629s.pdf

Zekri S, Dinar A. 2003. Welfare consequences of water supply alternatives in rural Tunisia. Agric Econ 28(1):1-12. https://doi.org/10.1111/j.1574-0862. 2003.tb00130.x 